\title{
LECTURERS' EXPERIENCES IN TEACHING SOFT SKILLS IN TEACHER PROFESSION EDUCATION PROGRAM (TPEP) IN INDONESIA
}

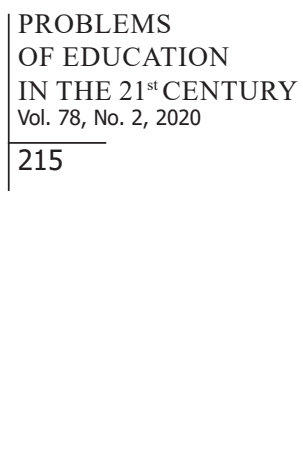

\author{
Jefri Mailool \\ Yogyakarta State University \& Manado State Christian \\ Institute (IAKN Manado), Indonesia \\ E-mail: jefri0018pasca.2018@student.uny.ac.id, jefri.mailool@iakn-manado.ac.id \\ Heri Retnawati, Samsul Arifin, Ameliasari \\ Tauresia Kesuma, Himawan Putranta \\ Yogyakarta State University, Indonesia \\ E-mail: heri_retnawati@uny.ac.id, samsularifin.2018@student.uny.ac.id, \\ ameliasaritauresia.2018@student.uny.ac.id, \\ himawanputranta.2017@student.uny.ac.id
}

\begin{abstract}
The Teacher Profession Education Program (hereafter abbreviated: TPEP) in Indonesia is a program designed to generate professional teachers. Every pre-service teacher must be equipped with adequate hard skills and soft skills before diving into a professional environment. This phenomenological research explored the lecturers' experiences in teaching soft skills to the students of TPEP. This research aims at getting a clear understanding of how soft skills teaching is implemented and what kinds of soft skills have been trained during TPEP. The data in this research were primarily collected through in-depth interviews conducted with 15 teaching lecturers from three universities that hold and organize the TPEP. Data analysis used analytic reduction which started from identifying important statements of the interview results, determining the core theme, and describing the essence of the entire experience. The results found that teaching soft skills with integrated/embedded models was used in the TPEP. Lecture, presentation, assignment, mentoring, and practice methods were used to train the TPEP students'soft skills. While the soft skills that have been trained during the implementation of the TPEP consist of ethics, self-reliance, responsibility, patience, critical thinking skills, communication skills, teamwork, tolerance, and social skills. The future research is expected to develop a criteria-based on integrated soft skills assessment model that can be used to assess the achievement of the acquisition of teachers'soft skills at the end of TPEP.
\end{abstract}

Keywords: pre-service teacher, soft skills, teacher profession education program (TPEP).

\section{Introduction}

The future becomes unpredictable because of the rapid changes in many aspects of life in the 21st century as the impact of the rapid development of technology (Kennedy, Latham, \& Jacinto, 2016), and these changes are increasingly getting stronger especially which occurred in the era of the fourth industrial revolution (Schwab, 2016). These changes have encouraged 
Jefri MAILOOL, Heri RETNAWATI, Samsul ARIFIN, Ameliasari Tauresia KESUMA, Himawan PUTRANTA. Lecturers' experiences in teaching soft skills in teacher profession education program (TPEP) in Indonesia

PROBLEMS

OF EDUCATION IN THE $21^{\text {st }}$ CENTURY Vol. 78 , No. 2, 2020

216

various sectors both government and private in some countries to respond with various strategies and policies (Menon \& Fink, 2019; Schäfer, 2018). In relation to those changes, governments have been required to be able to adapt and act quickly in responding to various existing issues and collaborate with people from all levels of society (Schwab, 2016).

Socio-economic and political areas have undergone many changes as a result of globalization in the 21 st century (Maphosa \& Mashau, 2014). In addition, economic shifts from industry-based to information-based have caused significant changes in the working world, even the resources of equipment used are very much different when compared to half a century ago (Griffin, McGaw, \& Care, 2012). Along with the journey of the century that is full of the rapidly changing social needs, the provision of relevant education becomes a new demand for the field of education (Jacobs, 2010; Pretorius, 2004; Trilling \& Fadel, 2009). These changes need to be responded with appropriate adjustments in the way of thinking and acting.

One of the important issues that becomes a point of intersection between higher education and the current workplace is the readiness of higher education graduates to face the increasingly competitive work market demands (Gupta \& Sharma, 2016; Griffiths, Inman, Rojas, \& Williams, 2018). Most competitive workplaces already use the assistance of computer technology but require a variety of skills from individual (Koenig, 2011). The global economic tendency in the 21 st century requires adequate education and work skills qualifications (Boyer \& Crippen, 2014). Trilling and Fadel (2009) suggested that trained workers who mastered digital equipment have been highly needed by the working world in the 21 st century. Moreover, mastery in terms of communication skills, global insight knowledge, collaboration, and innovation skills become the demands of the education and employment fields in the 21st century (Geisinger, 2016). This indicates that to meet the skill standard required by the working sector in the 21 st century obliges every prospective worker preparing himself with adequate skills to be able to compete in the increasingly tougher workforce recruitment.

The current job market becomes more and more competitive, so every prospective worker should bring his or her own excellencies that distinguish him or her from other prospective workers (Gupta \& Sharma, 2016). This means that prospective workers should show a certain quality of excellence to distinguish themselves from other competitors, such as the excellence of character that has the potential in making their academic and technical skills effective. The advantage side concerning the character aspects in this research was related to soft skills.

The pre-service teachers are part of these prospective workers, and they are also required to have a competitive advantage. To become a more desirable teacher, pre-service teachers must equip themselves with adequate soft skills (Li \& Tien, 2011). Therefore, becoming a qualified teacher, the acquisition of soft skills has been very essential in addition to aspects of knowledge and pedagogical competence (Muhammad, Lebar, Mokshein, \& Baharom, 2017).

Soft skills become a crucial part of the learning themes found among the disciplines in the 21 st century besides information, media, and technology skills (Trilling \& Fadel, 2009). Kereluik, Mishra, and Fahnoe (2014) synthesized 15 of 21 st-century learning frameworks and organized them into models based on three large groups of knowledge, i.e. the foundational knowledge that has represented the hard skills, the humanistic knowledge, and the meta knowledge which describes the soft skills.

The launch of these important themes for 21 st-century learning is closely related to the demands and needs of this era. Aspects related to values and skills will serve as a key solution to global problems (Gupta \& Sharma, 2016). Wilmarth (2010) stated that technological trends and social adaptations have had a profound effect on education in the 21 st century. Meanwhile, when reviewing the functional theory and the conflict of educational stratification posed by Collins (1971), it was found that the role of education in a functional facet has been designed in order to equip members of the community with quality and skills that are in accordance with the socio-economic conditions. The theory is in line with the thought by Fallows (2003), stating 
that the working world has required modern graduates to be equipped with various types of skills and clearly understand the scope of those skills functionally.

A number of literature reviews have shown an increased interest in soft skills, but ironically the academic program to develop them has been still far from expectation (Succi \& Canovi, 2019) since higher education is still more focused on hard skills (Arat, 2014). Whereas, the academic programs, particularly in higher education, must become the leading outpost for the manpower planning of a country (Sambell, Brown, \& Graham, 2017).

Soft skills become an essential skill every pre-service teacher must possess. The high level of soft skills owned by the teachers has shown that they will be more efficient in performing their tasks or jobs at school (Lavilles Jr \& Robles, 2017). However, an earlier research conducted by Tang and Tan (2015) found that beginner teachers have not considered ethics and moral skills as an essential soft skill needed in the workplace. In contrast, the mastery of soft skills by teachers will positively impact the achievement of education quality and professional development of the educators (Tan \& Tang, 2015).

In some sources, the terminology of social skill is often aligned with some other terms such as people skills (Sonmez, 2015), life skills (WHO, 1999), transversal competence (Cimatti, 2016; Succi \& Canovi, 2019), and even another recent term of CORE (Competence in Organizational and Relational Effectiveness) skills (Parlamis \& Monnot, 2018) which all tend to lead to basic skills that are not related to hard skills or technical skills.

Soft skills are essentially an intra-personal and inter-personal skill needed for selfdevelopment, social involvement and supporting work success (Kechagias, 2011). Soft skills include communication skills, collaboration skills, adaptability, etc. Soft skills enable a person to be effective and efficient in applying their knowledge and technical skills (Klaus, 2007; Joshi, 2017).

Sonmez (2015) interpreted the soft skills into the term of people skills as a very important skill for everyone since people do not live alone and always strive to connect effectively with others. Meanwhile, life skills (WHO, 1999) refer to the psychosocial ability allowing individuals to be effective at facing the demands and challenges of daily life. Transversal competencies, that are also aligned with soft skills, have been defined as competencies that have adequate portability and flexibility to function effectively in a constantly changing environment (Tsankov, 2017).

Transversal competencies are one of the competitive advantages required by every institution in the $21^{\text {st }}$ century. Cimatti (2016) suggested that transversal competencies have been needed despite being in the midst of an era where technology has become a decisive tool in winning the competition in working field. The ability to build communication, coordination, and harmonization, that represent transversal competencies, hence will be able to streamline the working environment so that the desired quality of work can be achieved (Cimatti, 2016).

The survey results of the World Economic Forum (WEF, 2016) revealed that problemsolving skills, social skills, and system skills have become desirable traits demanded by employers compared to physical abilities and content skills. This indicates that soft skills are becoming progressively important because some of the attributes of soft skills are proven to dominate the needs or demands of the labor market, especially in the second decade of the $21^{\text {st }}$ century.

Furthermore, soft skills are considered as the professional needs so that these skills need to be accommodated in the teacher education curriculum (Pachauri \& Yadav, 2014). The teaching of soft skills in higher education has been highly made possible through special training programs and embedded through their integration in every discipline or existing courses (Subramaniam, 2013; Pachauri \& Yadav, 2016; Cimatti, 2016). Moreover, the teacher education organized by the higher education has needed to teach soft skills as the basic skills that make up the work skills of pre-service teachers before entering the professional community (Griffiths, Inman, Rojas, \& Williams, 2018). 
Jefri MAILOOL, Heri RETNAWATI, Samsul ARIFIN, Ameliasari Tauresia KESUMA, Himawan PUTRANTA. Lecturers' experiences in teaching soft skills in teacher profession education program (TPEP) in Indonesia

PROBLEMS

OF EDUCATION

IN THE $21^{\text {st }}$ CENTURY

Vol. 78, No. 2, 2020

218

In the context of Indonesia, education for pre-service teachers is known as TPEP organized by universities that have had an accredited educational personnel procurement program established by the government (Kementerian Riset, Teknologi, dan Pendidikan Tinggi, 2017). TPEP is expected to produce professional teachers who are able to work effectively especially in answering the demands and needs of this era.

\section{Research Problem}

The acquisition of soft skills is important for pre-service teachers, especially to make their pedagogical practices effective. However, the facts have shown that soft skills possessed by teachers were still low (Fadli \& Irwanto, 2020; Tang, Yunus, \& Hashim, 2015). The low proficiency of the teachers' soft skills is often demonstrated by the less effective learning management performed by the teachers. In fact, the effectiveness of the learning management performed by the teachers will expectedly increase the achievement of students' learning outcomes. On the other hand, when the teachers possess inadequate soft skills, it usually brings about a negative impact on the school climate. Therefore, this situation eventually can result in the difficulties in achieving the school goals.

Soft skills are also an important part of the teachers' competencies. The fact, however, shows that the teachers generally still possess inadequate competences, and this situation can be interpreted as one of the evidences that the teachers' soft skills are still not as much as expected (Assifa, 2019). Tang and Tan (2015) revealed that pre-service teachers found the soft skills that they got from teachers' professional training were not enough to be applied in their workplaces. With this regard, Tang, Tan, and Vetriveilmany (2015) also stated that the lack of soft skills was largely due to the education system which is less effective in developing their students' soft skills. Thus, the importance of soft skills teaching in teacher education institutions is seen as a way to produce quality teachers. However, to what extent this soft skills teaching is carried out in teacher education institutions needs to be explored in depth. Therefore, exploration of lecturers' experience in teaching soft skills to pre-service teachers in TPEP needs to be done.

\section{Research Questions}

Realizing the significance of soft skills for pre-service teachers and their role in supporting the improvement of education quality, this research was specially aimed to explore soft skills teaching models and types of soft skills taught during TPEP implementation. The research, thus, was directed to answer the following research questions:

1. How does the TPEP lecturers teach soft skills during the implementation of the teacher profession education program?

2. What kinds of soft skills have been trained during the implementation of TPEP?

\section{Research Focus}

This phenomenological research focused on highlighting the experience of TPEP lecturers in teaching of soft skills to pre-service teachers in the TPEP. The soft skills intended in this research was a generic soft skill, which is applicable for cross-discipline in TPEP, both in the scope of early childhood education, primary education, as well as for secondary education. 
Jefri MAILOOL, Heri RETNAWATI, Samsul ARIFIN, Ameliasari Tauresia KESUMA, Himawan PUTRANTA. Lecturers' experiences in teaching soft skills in teacher profession education program (TPEP) in Indonesia

\section{Research Methodology}

\section{General Background}

This research was a qualitative research that used the transcendental phenomenological approach (Moustakas, 1994). This research was conducted to explore more information about the experience of participants in the implementation of TPEP. Specifically, this research was aimed to get an in-depth understanding of how to teach soft skills to pre-service teachers and what kinds soft skills have been trained in the implementation of TPEP. This research was conducted for 4 months starting from August to November 2019. This research is expected to be the basis for further research, more especially in order to develop a more qualified and sustainable TPEP.

\section{Participants}

Participants in this research were 15 lecturers of the TPEP study program in Special Region of Yogyakarta (D.I.Y Province) and Central Java province. The participants of this research were 15 people based on the design proposed by Creswell (2007) stating that the exploration of phenomena can be carried out on heterogeneous participants between 3 to 15 people. The three college or university names received appellation as $\mathrm{C} 1, \mathrm{C} 2$, and $\mathrm{C} 3$. The purpose of the disguised college identity is to protect research participants through ensuring the confidentiality of information shared and also anonymity (EdQual Research Program Consortium, 2006). In addition, before conducting the data collection, researchers established a relationship with the universities involved in this research, including individuals who participated in this research. The researchers did this in order to get approval, and therefore it made this research group easier to conduct the data collection process. The researchers selected the three colleges as samples for data collection because not only they fulfilled administrative requirements as TPEP organizing as determined by the government, but they also characteristically represented a number of TPEP organizing universities in Indonesia. In detail, the characteristics of the participants in this research are shown in table 1.

\section{Table 1}

Demographic profile of the participants

\begin{tabular}{|c|c|c|c|c|c|c|c|}
\hline \multirow{3}{*}{ University } & \multicolumn{6}{|c|}{ Implementation Level of TPEP } & \multirow{3}{*}{ Total } \\
\hline & \multicolumn{2}{|c|}{$\begin{array}{l}\text { Early Childhood } \\
\text { Education Program }\end{array}$} & \multicolumn{2}{|c|}{$\begin{array}{l}\text { Primary Education } \\
\text { Program }\end{array}$} & \multicolumn{2}{|c|}{$\begin{array}{c}\text { Secondary Education } \\
\text { Program }\end{array}$} & \\
\hline & Male & Female & Male & Female & Male & Female & \\
\hline C1 & - & 1 & 1 & 1 & - & 2 & 5 \\
\hline C2 & - & 2 & 1 & - & 1 & 1 & 5 \\
\hline C3 & - & 1 & 2 & 1 & 1 & - & 5 \\
\hline
\end{tabular}


Jefri MAILOOL, Heri RETNAWATI, Samsul ARIFIN, Ameliasari Tauresia KESUMA, Himawan PUTRANTA. Lecturers' experiences in teaching soft skills in teacher profession education program (TPEP) in Indonesia

PROBLEMS

OF EDUCATION

IN THE $21^{\text {st }}$ CENTURY

Vol. 78, No. 2, 2020

220

\section{Instrument and Procedures}

The data collection in this research was mainly conducted through in-depth individual interviews (Creswell, 2007). Interviews were conducted in a duration of 45 to 90 minutes. The interviews were generally done at the participants' campus, but there were some of the participants who were willing to have interview outside the campus. Considering the quality of the recorded results of the interviews, researchers proposed to the participants that the interview should be conducted indoors to minimize unwanted noise. The interview questions were open and general in nature, compiled by researchers to understand the core phenomenon of this research (Creswell, 2015). During the interview, the researchers tried to create a conducive climate that made the participants feel comfortable and free in responding to every question raised (Moustakas, 1994). In this case, researchers avoid questions that have the potential to open sensitive information and are difficult to answer by participants. These things are done by researchers to show respect for the participants' self-presence.

\section{Data Analysis}

Analytic reduction of participants' experiences in implementing the TPEP became an important part of data analysis in this research. The steps of data analysis were classified into important statements, central themes, and the essence descriptions of the experience of the overall phenomenon (Moustakas, 1994). Moustakas (1994) stated that the description of the essence is what is being experienced and how the individual encounters these experiences. The data analysis procedure in this research began by converting the voice record from the interview into transcript so that it can be easily checked for various information contained. The researchers carefully read the interview transcript several times. Along with this process, the researcher also selected the important information contained in it into important statements. Important statements identified by the researcher are further grouped into a central theme. These important statements and central themes are then used to create textural descriptions, i.e. descriptions of what is experienced by the participants. Important statements and central themes are also used by researchers to make structural descriptions, i.e. descriptions of how participants experience the phenomenon. The final step in this data analysis procedure was to write the essence of the whole phenomenon experienced by the participants. The description of the essence is a combination of textural and structural description that revealed the essence of the phenomena experienced by the participants.

\section{Research Results}

Before describing the results of this research, it is important to illustrate in general about the TPEP carried out in Indonesia. The TPEP is an educational program organized to prepare Bachelor Degree of Education (S1) graduates and S1/D-IV of Non-Education graduates, who have talent and interest to be professional teachers, in order to master the competence of a teacher as a whole in accordance with the national education standards so as to obtain a certificate of professional educators on early childhood education, primary education, and secondary education (Kementerian Riset, Teknologi, dan Pendidikan Tinggi, 2017). The main objective of this program is to create professional teachers who are able to produce qualified graduates who can answer the demands of today's time (Kementerian Riset, Teknologi, dan Pendidikan Tinggi, 2017). In short, an overview of the Teacher Profession Education system is presented in Figure 1 below. 


\section{Figure 1}

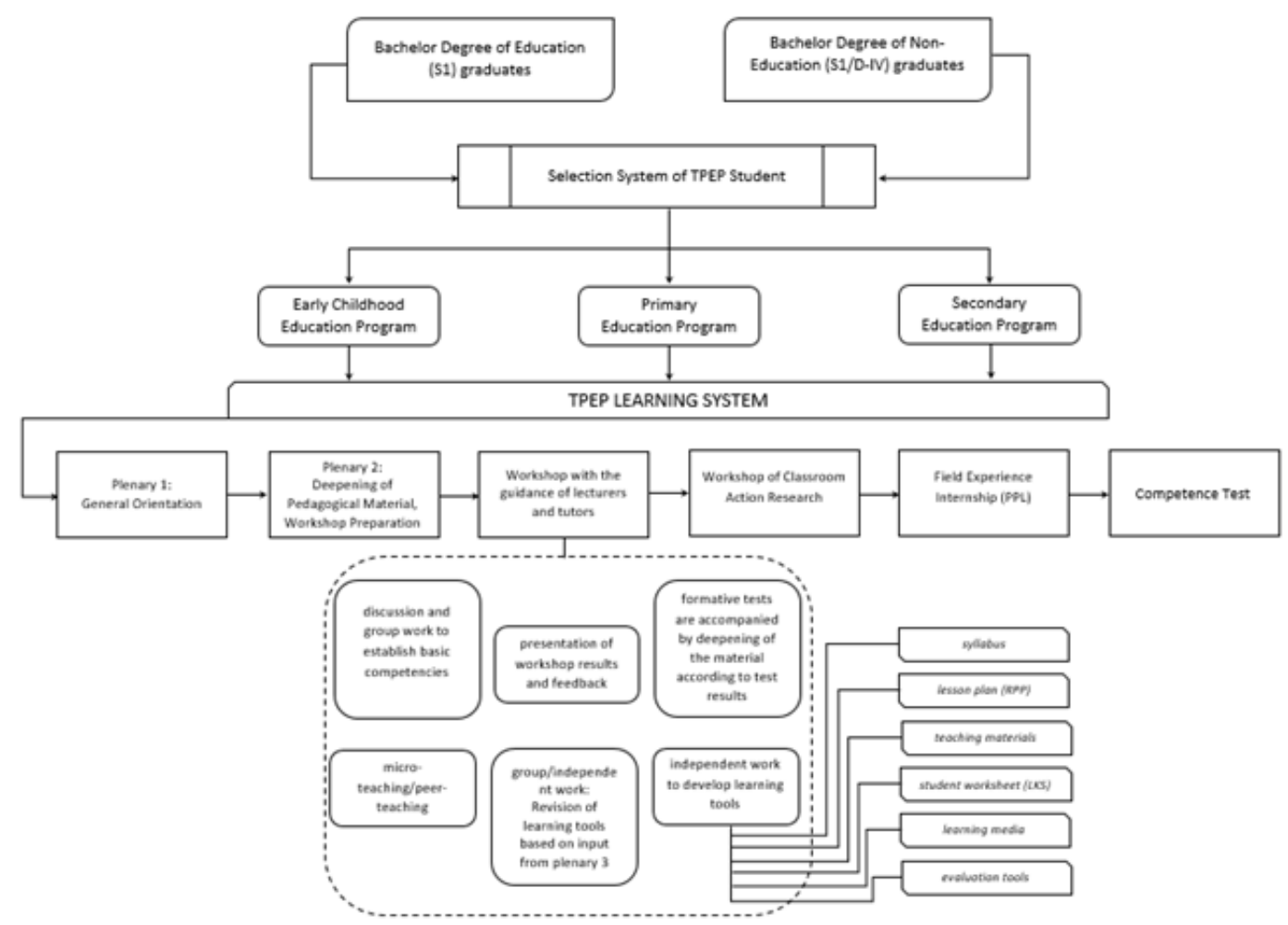

The results of this research are outlined through a textural and structural description based on important statements and central themes of the lecturers' experiences in the teaching of soft skills during the implementation of the TPEP, which were then concluded with the essence of the overall experience of the phenomenon.

\section{Central Themes and Important Assertions about Teaching of Soft Skills during the Implementation of TPEP}

In the implementation of TPEP, the soft skills teaching model was integrated into every existing course. The TPEP curriculum did not contain courses that specifically teach soft skills. A TPEP lecturer revealed that "explicitly, special courses that teach soft skills are not listed in the curriculum but there are assessments of the process such as critical thinking, cooperation... and such things are observed in the workshop process". Another lecturer also said that "for training that is directly specific to particular soft skills, it does not exist in TPEP... the workshop activities in TPEP, the learning is a direct one from material deepening like making the learning devices". Another similar statement was expressed by a lecturer, where "the target of TPEP is to complete the device, classroom action research proposal, peer teaching, academic and non-academic, and then the exam". There was also one participant who said that "in the TPEP curriculum, there does not appear the presence of a course that specifically teaches soft skills". TPEP curriculum included workshop courses and Field Experience Internship (hereafter abbreviated PPL). Competencies related to soft skills were integrated into each course. 
Jefri MAILOOL, Heri RETNAWATI, Samsul ARIFIN, Ameliasari Tauresia KESUMA, Himawan PUTRANTA. Lecturers' experiences in teaching soft skills in teacher profession education program (TPEP) in Indonesia

PROBLEMS

OF EDUCATION IN THE $21^{\text {st }}$ CENTURY Vol. 78, No. 2, 2020

222

During the learning process in the TPEP, soft skills were taught to students in a variety of teaching methods, including lecture. Lectures delivered by TPEP lecturers were, in addition to theories, aimed at teaching aspects of hard skills, also combined with the teaching of soft skills. Lectures that engage soft skills teaching were primarily focused merely on ethics. Ethics was seen as an important thing for pre-service teachers to possess. Therefore, in their lectures, TPEP lecturers always emphasized the importance of ethics to be the inherent trait for each preservice teacher. The TPEP lecturers delivered lectures on the position of a teacher in the eyes of others, especially from the students' points of view. Lectures taught soft skills that were contextual because they were related to real-life experiences. "During the lectures, I tell them what their position looks like and what attitudes they should be doing". The lecturer said that "while in the class, what behavior should teachers do, how his or her manner... including how he or she dresses, how to deal with the students, and the likes that I will give in my lectures". In the lecture, the lecturer also conveyed that patience was an important thing every pre-service teacher should have since they need patience in dealing with various students' characters, they need the patience to guide their students". "Patience is an important thing in order to confront with less disciplined students".

Soft skills teaching by TPEP lecturers was also done through mentoring. The mentoring here related to how the TPEP lecturer directed the student attitudes to reflect the appropriate attitude as a professional teacher candidate. Sometimes, from the observations of a lecturer, there were a few students who violated ethics and program regulation during the implementation of TPEP. A TPEP lecturer said, "I do observations, and when there are participants whose behavior does not reflect what is supposed to be a teacher, I will reprimand them and explain that the position of the teacher should be like this and that so they can put themselves as a professional teacher candidate figure". The TPEP lecturers had a strong commitment to guide their students to have an attitude that reflects themselves as a professional teacher.

In addition to lectures and mentoring, in the workshop activities, TPEP lectures trained the critical thinking skills of TPEP students through the practice of making learning devices. Learning devices were a tool that teachers used in implementing the learning process. Constructing learning devices required critical thinking skills. A TPEP lecturer said, "to develop learning devices, students must think critically because there is a process within which they must analyze carefully". Another TPEP lecturer also stated, "critical thinking is needed to design learning devices ... without thinking critically they certainly cannot do it". Critical thinking skills were also trained in the form of classroom action research practices. To carry out a classroom action research, it requires critical thinking so that the results of the research would be scientific and able to answer the problems examined. "In conducting a classroom action research, it is obvious that they need to think critically, describe the problems they encountered, gather data, and find the right solution to the problems".

Another form of soft skills teaching performed by TPEP lecturers was through presentation activities. Students were given the opportunity to present their classroom action research report. Thus, students were trained to be able to communicate scientifically through the explanation of their classroom action research projects. "The classroom action research that they produce must be presented, and from there we assess their performance, about how they convey ideas orally". In addition to presentation methods, the communication skills of TPEP students were also trained through peer teaching activities. One of the lecturers said, "This peer teaching activity trains them to teach well in front of the class". Through peerteaching activities, students learned to teach effectively so that the way they deliver or present the learning materials became highly emphasized.

In the workshop activities, lecturers also gave tasks that were individual as well as group or collective assignments to the students. Given the assignments, students were trained to be independent, responsible, and able to build cooperation with others (teamwork). A lecturer 
stated that "I give them a task, in addition to assess their ability, also to train them to get used to be independent and accountable to their works". Another statement was also asserted by a lecturer who said that "I give them group assignments to train them in forms of cooperation and how they will contribute to their group".

Another soft skill teaching in the implementation of TPEP was about tolerance. Tolerance among TPEP students was taught by lecturers through lectures during workshop activities. In particular, for the Islamic University of TPEP organizer, there was additional material, namely the moderation of Islam. This material was the recommendation of the Ministry of Religious Affairs of the Republic of Indonesia in order to instill tolerance as an attempt to face the phenomenon of radicalism emerging lately. One lecturer said, "We also teach the Islamic moderation material as a recommendation from the Ministry of Religious Affairs because we now are facing the phenomenon of radicalism." The lecturer also stated, "Of course teachers need to know about this since they, later on, will teach the values of collective life in the early childhood education". In addition to lectures, tolerance was also formed in the dormitory environment. This was illustrated in the statement of a TPEP lecturer who asserted that "in a dormitory, they are trained to accept diversity, to respect each other". Another lecturer also said, "when Christian students are praying, Moslem students will contribute to maintain the atmosphere of the dorm to remain conducive, and vice versa".

Social skills were not the least important soft skill for a teacher. The social skills of TPEP students were trained through PPL activities at a partner school of the TPEP organizer universities. In the interview, a lecturer said that "In the PPL of TPEP ...there are academic and non-academic... the non-academic one is about how he blends there and being a part of ... eh... the school institution". This suggested that the PPL process required students to interact with all elements of the school. In interacting, it certainly required good relationship building skills with others. A TPEP lecturer also stated that "PPL trains them how to teach students and interact with everyone in the school environment".

\section{The Essence of Lecturers' Experiences in Teaching Soft Skills in the TPEP}

The essence of the overall lecturers' experiences in teaching soft skills in the TPEP also answered two basic questions in the research at once. In the TPEP, the teaching of soft skills for pre-service teachers was integrated or embedded in each course programmed in the curriculum. It meant that the teaching of soft skills was not separated from hard skills teaching, rather it took place at the same time. The TPEP lecturers taught soft skills in a variety of teaching methods according to the context and purpose of the learning. Various teaching methods were conducted by TPEP lecturers including lectures, mentoring, student presentations, independent and group assignments, and practical activities carried out through the implementation of PPL, peer teaching, drafting learning devices, and classroom action research practices. The lecturers' experiences in teaching soft skills to TPEP students generally took place in classroom learning activities by using methods such as lectures, mentoring, presentations, and practices. In addition to the classroom learning activities, students learned soft skills that also occurred at the partner school of TPEP university that organized and provided TPEP through PPL activities. The PPL was carried out by the supervision of a teacher-mentor and TPEP lecturer who was appointed as the field supervisor. Therefore, TPEP lecturers were highly contributing to the establishment of soft skills of students during PPL implementation. The establishment of students' soft skills also occurred in the dorm environment where TPEP students stayed. This was related to the institutional policy of the TPEP organizers who directed their students to stay together in a dormitory, especially those that came from outside the region. 
Jefri MAILOOL, Heri RETNAWATI, Samsul ARIFIN, Ameliasari Tauresia KESUMA, Himawan PUTRANTA. Lecturers' experiences in teaching soft skills in teacher profession education program (TPEP) in Indonesia

PROBLEMS

OF EDUCATION IN THE $21^{\text {st }}$ CENTURY Vol. 78 , No. 2, 2020

Through in-depth interviews on the lecturers' experiences in teaching soft skills in the implementation of TPEP, it was found various soft skills that had been trained to students. These soft skills were, among others, ethics, patience, critical thinking, communication skills, independence, responsibility, teamwork, tolerance, and social skills. Ethics was seen as a soft skill that was important for a pre-service teacher. The position of the teacher as a person who should be an example for students needed to be well-maintained. This ethics teaching was done by TPEP lecturers through a method of lecture in the learning classroom. As well as other soft skills such as patience and tolerance were also taught through lecturing methods. Tolerance, however, was also trained to students through life in dormitories. Students' critical thinking skills were trained through practice activities especially in constructing learning devices and also classroom action research. Like communication skills, it was trained by TPEP lecturers in the classroom learning through student presentation and peer teaching activities. This presentation and peer teaching activities trained the students to be able to communicate orally well from the way they delivered their ideas. Like teamwork skills, responsibility, and self-reliance were all given by the TPEP lecturers through the method of assignments. Those assignments were in the forms of individual and also group assignments. With that method of assignment, students' independence in working would be established and a sense of responsibility would be fostered to complete and to finish their tasks. On the other hand, the tasks given for group work would train students about how they collaborate with each other in the group to accomplish the tasks as their mutual responsibility. Finally, the social skills related to student interaction with their surrounding environment. Students were trained the social skills of TPEP through PPL activities. In addition to sharpening the academic competencies of students through their involvement in their teaching practice, this PPL activity also trained students to associate with themselves or to mingle with and live together in a school environment. In this case, social skills were indispensable for interacting with all elements of the school.

\section{Figure 2}

Soft skills teaching in the TPEP

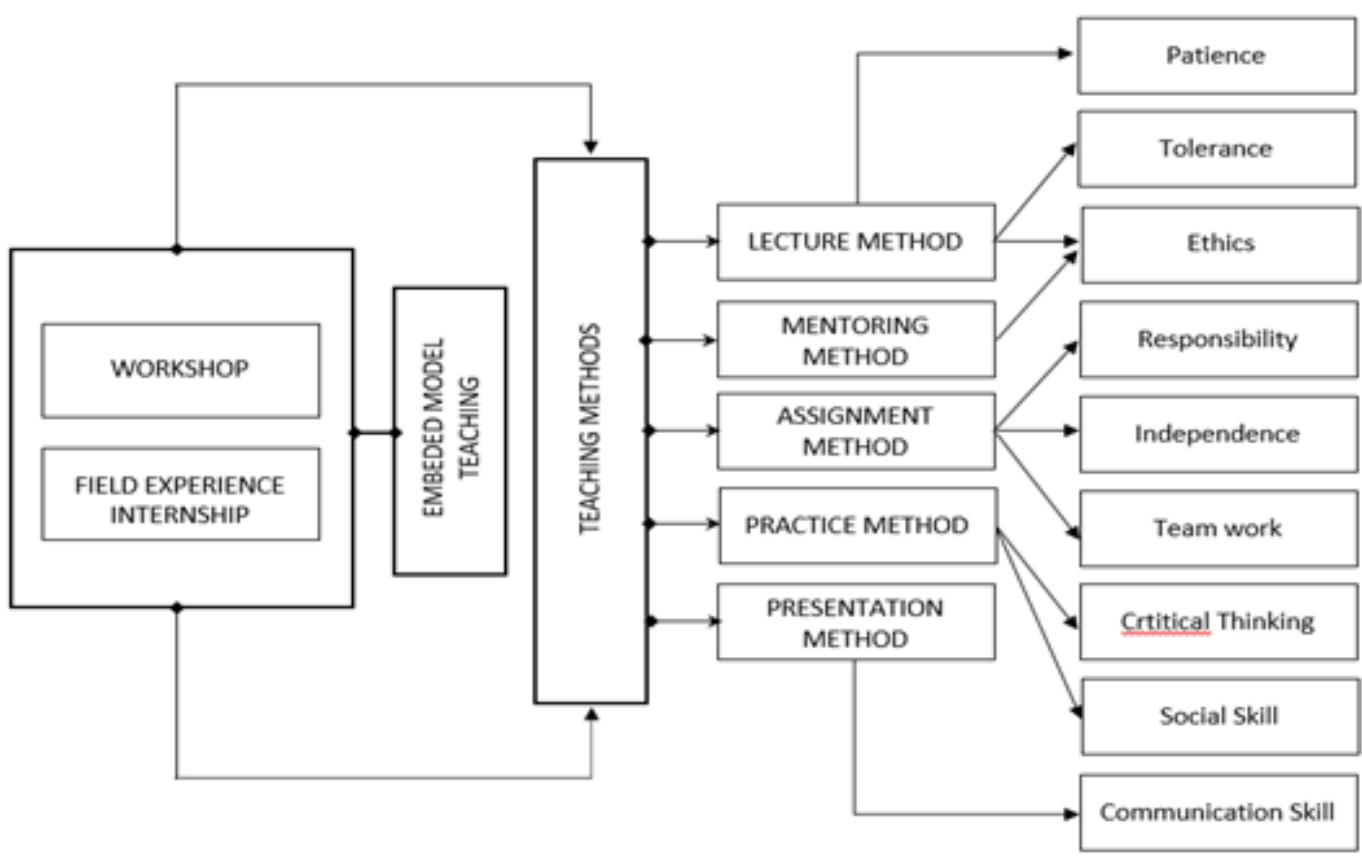


The acquisition of soft skills was very important for every pre-service teacher, thus soft skills needed to be well taught to the students of pre-service teachers. The research has revealed that the teaching model of soft skills in the TPEP used an integrated or embedded model on every existing course. The teaching of soft skills in the TPEP was integrated into two core courses, i.e. Workshop and PPL. These kinds of soft skills teaching models were widely supported. The research results by Tang et.al (2015) stated that the soft skills component implanted in curriculum design has been an alternative solution in teaching soft skills. Moreover, the research results by Majid, Liming, Tong, \& Raihana (2012) showed that, in general, students have preferred the model of soft skills training that has been embedded in the course as it can give them the opportunity to understand how to implement these skills in certain situations. Teaching soft skills with an embedded model requires the lecturers' ability in terms of mastering the teaching methods. These teaching methods were very essential, because the teaching of soft skills with an embedded model was fully student-centered in nature (Pachauri \& Yadav, 2014). Therefore, the use of student-centered teaching methods should be applied to teaching soft skills. However, the results of this research disclosed that in the workshop activities, methods like lectures were also used to teach soft skills to the TPEP students. Though, the lecture method itself was a conventional learning method centered on the lecturers. Consequently, the effectiveness of the use of lecture methods in teaching soft skills needed to be proved through the assessment of students' soft skills at the end of the program. The research results also demonstrated that the lecturing method was used widely by the lecturers as a means to convey the importance of ethics for every pre-service teacher. Ethics was valued as a soft skill that every pre-service teacher must possess. The notion was strengthened by the research findings of Tang \& Tan (2015) stating that the school administrators have viewed the ethics and moral skills as the most needed soft skills in the school environment. Therefore, it was highly appropriate if the ethics was delivered during the implementation of the TPEP.

Another method for teaching soft skills found in this research was a presentation. The presentation method was considered to be one of the effective methods to practice the communication skills of TPEP students. Through presentations, students were trained to communicate their various ideas. In order to get the ideas understood properly by the audience, the proper diction selection should be a special concern of each communicator. Therefore, the presentation method became the right tool in practicing the communication skills of TPEP students, which was an important part of the soft skills that every pre-service teacher had to have. Every pre-service teacher should be able to communicate well since one of the teacher's jobs was to transfer knowledge including diverse "values" to his or her students (Lewis, 2018). The knowledge transfer process would run effectively if supported by adequate teacher communication skills. Students would be easier to understand the subject matter if the teacher delivered it in a language that was easy to understand. Therefore, the proper diction selection needed to be taken into account by the teacher during the knowledge transfer process. Another method that also employed to train the TPEP students' communication skills was through peer-teaching activities. This peer teaching activity was highly essential in training students' communication skills because within this activity there was a teaching practice performed by student teachers to their peers. In teaching, it certainly required the ability to communicate so that the material delivered could be well-understood.

Independence and responsibility were soft skills that were also trained during implementation of TPEP. Giving self-duty or individual project was a method used by the lecturers to train the attitude of self-reliance and responsibility of TPEP students. This was very reasonable because integrating soft skills into the curriculum did not mean that there was a new topic added in the teaching curriculum, rather the soft skills that would be trained could 
Jefri MAILOOL, Heri RETNAWATI, Samsul ARIFIN, Ameliasari Tauresia KESUMA, Himawan PUTRANTA. Lecturers' experiences in teaching soft skills in teacher profession education program (TPEP) in Indonesia

PROBLEMS

OF EDUCATION IN THE $21^{\text {st }}$ CENTURY Vol. 78 , No. 2, 2020

226

be embedded in tasks or projects related to existing subject matters (Tang, Yunus, \& Hashim, 2015). For a teacher, independence and a sense of responsibility were things that needed to be demonstrated in performing his or her tasks at school. Without independence, teachers would not be able to develop their creativity and professionalism. Likewise, responsibility was crucial because educating the students and producing quality graduates was the responsibility of each teacher.

In addition to responsibility and independence, another soft skill that was trained in teacher professional education program was the teamwork skills. This research discovered that teamwork skills were given by the TPEP lecturers and trained through group assignments. Group assignments shared a mutual responsibility to each member of the group. Therefore, to carry out or to complete the tasks required coordination among the group members. With this mutual coordination, the collaboration process would take place well. This was in accordance with the research results by Zhang (2012), unveiling that the task/group project would allow the creation of a teamwork environment. Teamwork in the school environment was a supporting factor for the achievement of each school program. Moreover, good cooperation among all elements of the school principal, teacher, and staff would create a conducive school climate. Hence, teamwork skills were an important skill and a must-have for every pre-service teacher.

Critical thinking meant to think in analytical and evaluative ways (Cottrell, 2005). Critical thinking is an essential soft skill for a teacher. This research results showed that critical thinking skills were trained in the TPEP through learning device creation activities and classroom action research practices. The creation of learning devices requires critical thinking because learning devices were tools to carry out processes that enabled educators and learners to engage in learning activities. It was, therefore, important to involve analytical and evaluation processes in the creation of learning devices. Through critical thinking, teachers would be able to design high-quality learning. Similarly, classroom action research required critical thinking skills from TPEP students. Research is essentially a scientific process. Classroom action research is a research intended to improve learning in the classroom. As a result, to conduct research certainly requires critical thinking.

In global community life, diversity is a thing that it is necessary to be well-managed. The difference is everywhere, and it requires an attitude to be able to respect and accept such differences as a form of self-consciousness that every human being is a unique creature. An attitude that is able to respect these diverse differences is understood as tolerance. Tolerance is necessary to be taught in the scope of the education field. The results of this research showed that tolerance was taught by TPEP lecturers as soft skills and that must be possessed by every pre-service teacher. The lecturers taught tolerance to the TPEP students through lectures in workshop activities. Even for TPEP organized by an Islamic university, there was a special material that discussed the moderation of Islam as recommended by the Ministry of Religious Affairs of the Republic of Indonesia. The course material was a form of government attention in the effort to combat the phenomenon of radicalism which lately became a serious problem. Many institutions realized that understanding the attitude of tolerance should be taught since early childhood in the educational environment through the role of a teacher in the teaching process. It is in line with the research by Baklashova et.al (2015) stating that tolerance has been important to be taught as early as possible to the young generation so that they were aware of the differences among humankind. In addition to being discussed or delivered in lectures during the workshop activities, tolerance attitude among TPEP students also formed in the life in the dormitory. The internal policy of the TPEP organizers directed their students to stay in dormitories. This policy surely had the objective that TPEP students who came from different backgrounds, especially from different cultural and religious background, could understand each other and appreciate the differences. Through this way, tolerance could increasingly develop. 
PROBLEMS

OF EDUCATION

IN THE $21^{\text {st }}$ CENTURY

Vol. 78 , No. 2, 2020

Regarding the issue of background differences that each individual might bring into a particular community, hence the aspect of social skills was very defining for the formation or establishment of conducive social interactions. Social interactions involve some basic skills such as communication, ethics, teamwork, and even self-awareness that are needed within. So, social skills are complex soft skills with some basic skills necessary to build interaction with others. The results of this research found that the social skills of TPEP students were formed through PPL activities in partner schools. PPL activities required students to get along with life in a school. The process of association with the school environment brought every PPL student to interact with all elements of the school (students, teachers, school staff, school principal). As a consequence, it would bring about a new experience where social skills must be part of their lives to build social interactions in the school environment.

\section{Conclusions and Implication}

This research described the lecturers' experiences in teaching the soft skills to students of pre-service teacher in the TPEP. This research explored the teaching models, the methods used, and the various types of soft skills that were trained during the implementation of TPEP. The research results showed that the teaching of soft skills in the TPEP adopted the integrated/ embedded model in each course. This integrated model was very effective to be used since it could combine the teaching of hard skills and soft skills. Outside the context of the TPEP, this integrated teaching model was suitable for all disciplines in higher education without exception.

The research also found that the use of soft skills teaching methods was varied according to the context and purpose of learning. Methods of lectures, presentations, assignments, mentoring, and practice were employed to train the soft skills of pre-service teachers. However, the effectiveness of the use of each teaching model had to be proved by the assessment or evaluation of soft skills at the end of the program. Unfortunately, there have been no guidelines for the soft skills assessment individually designed to assess the acquisition of soft skills by each pre-service in the TPEP. For that reason, thus, the future studies are expected to design a criterion-based assessment model that specifically assesses TPEP students' soft skills. The assessment model is useful to assess or evaluate the extent to which the soft skills are acquired by TPEP students during the program implementation. This is an important thing for TPEP organizing institutions in order to improve the quality of TPEP.

The research results showed that ethics, responsibility, patience, self-reliance, critical thinking skills, communication skills, teamwork, tolerance, and social skills were the soft skills that were trained during the implementation of TPEP. This range of soft skills was essential for every pre-service teacher before diving into a professional environment of schools. These various soft skills were useful in streamlining effectively the existing hard skills already mastered. Schools as a working field for educators desperately needed strong teachers in terms of characters, skilled in teaching, and qualified in terms of scholarly. Teacher education institutions must also be equipped with an adequate set of teaching methods as a tool to produce qualified teachers in the future. The time is changing, followed by various new demands for work skills, which should be anticipated by educational institutions through the development of new teaching methods that are more effective and flexible. 
Jefri MAILOOL, Heri RETNAWATI, Samsul ARIFIN, Ameliasari Tauresia KESUMA, Himawan PUTRANTA. Lecturers' experiences in teaching soft skills in teacher profession education program (TPEP) in Indonesia

PROBLEMS

OF EDUCATION

IN THE $21^{\text {st }}$ CENTURY Vol. 78, No. 2, 2020

228

\section{References}

Arat, M. (2014). Acquiring soft skills at university. Journal of Educational and Instructional Studies in the World, 4(3), 46-51. http://www.wjeis.org/FileUpload/ds217232/File/09.arat.pdf

Assifa, F. (2019, November 25). Kompetensi guru rendah, komisi X usul pendidik disekolahkan di luar negeri [Teacher competency is low, commission X of the Indonesian Legislative Assembly proposes that teachers study abroad]. Kompas. https://regional.kompas.com/read/2019/11/25/05443781/ kompetensi-guru-rendah-komisi-x-usul-pendidik-disekolahkan-ke-luar-negeri?page=all

Baklashova, T. A., Galishnikova E, M., \& Khafizova L, V. (2015). The effects of education on tolerance: research of students' social and ethnic attitudes. Mediterranean Journal of Social Sciences, $6(1$ S3), 335-340. http://doi.org/10.5901/mjss.2015.v6n1s3p335

Boyer, W., \& Crippen, C. L. (2014). Learning and teaching in the 21st century: An education plan for the new millennium developed in British Columbia, Canada. Childhood Education, 90(5), 343-353. http://doi.org/10.1080/00094056.2014.952218

Cimatti, B. (2016). Definition, development, assessment of soft skills and their role for the quality of organizations and enterprises. International Journal for Quality Research, 10(1), 97-130. http:// doi.org/10.18421/ijqr10.01-05

Collins, R. (1971). Functional and conflict theories of educational stratification. American Sociological Review, 36(6), 1002-1019.

Cottrell, S. (2005). Critical thinking skills: Developing effective analysis and argument. Palgrave Macmillan.

Creswell, J. W. (2007). Qualitative inquiry \& research resign: Choosing among five approaches (2nd $e d)$. Sage.

Creswell, J. W. (2015). Penelitian kualitatif \& disain riset: Memilih diantara lima pendekatan [Qualitative inquiry \& research design: Choosing among five approach]. Pustaka Pelajar.

Fadli, A., \& Irwanto. (2020). The effect of local wisdom-based ELSII learning model on the problem solving and communication skills of pre-service islamic teachers. International Journal of Instruction, 13(1), 731-746. http://doi.org/10.29333/iji.2020.13147a

Fallows, S. (2003). Teaching and learning for student skills development. In H. Fry, S. Ketteridge, \& S. Marshall, A handbook for teaching \& learning in higher education. Second edition. (pp. 122). Kogan Page.

Geisinger, K. F. (2016). 21st century skills: What are they and how do we assess them? Applied Measurement in Education, 29(4), 1-12. https://doi.org/10.1080/08957347.2016.1209207

Griffin, P., McGaw, B., \& Care, E. (2012). Assessment and teaching of 21st century skills. In P. Griffin, B. McGaw, \& E. Care (Eds.), The changing role of education and schools (pp. 2). Springer. http:// doi.org/10.1007/978-94-007-2324-5

Griffiths, D. A., Inman, M., Rojas, H., \& Williams, K. (2018). Transitioning student identity and sense of place: future possibilities for assessment and development of student employability skills. Studies in Higher Education, 43(5), 891-913, http://doi.org/10.1080/03075079.2018.1439719

Gupta, S., \& Sharma, S. (2016). Human values and soft skills development in education. International Journal of Humanities \& Social Sciences Studies, 3(3), 286-291. http://oaji.net/articles/2016/1115-1480922737.pdf

Halai, A. (2006, November). Ethics in qualitative research: Issues and challenges. EdQual research programme consortium on implementing education in low income countries (Paper No.4), Berkeley Square, Bristol.

Jacobs, H. H. (2010). Upgrading content: Provocation, invigoration, and replacement. In H. H. Jacobs (Ed.), Curriculum 21: Essential education for a changing world (pp. 35). ASCD.

Joshi, M. (2017). Soft skills. https://bookboon.com/en/soft-skills-ebook

Kechagias, K. (2011). Teaching and assessing soft skills. http://research.education.nmsu.edu/ files/2014/01/396_MASS-wp4-final-report-part-1.pdf

Kennedy, I. G., Latham, G., \& Jacinto, H. (2016). Education skills for 21st century teachers: Voices from a global online educators' forum. Springer.

Kereluik, K., Mishra, P., Fahnoe, C., \& Terry, L. (2014). What knowledge is of most worth: Teacher knowledge for 21st century learning. Journal of Digital Learning in Teacher Education, 29(4), 127-140. http://doi.org/10.1080/21532974.2013.10784716 
Koenig, J. A. (2011). Assessing 21st century skills: Summary of a workshop. The National Academic.

Lavilles Jr, H. L., \& Robles, A. C. (2017). Teachers' soft skills proficiency level and school performance IN THE $21^{\text {st }}$ CENTURY Vol. 78, No. 2, 2020 of selected schools in Sultan Kudarat Division. Journal of Advances in Humanities and Social Sciences, 3(1), 10-28. https://tafpublications.com/gip_content/paper/jahss-3.1.2.pdf

Lewis, P. (2018). Globalizing the liberal arts: Twenty-first-century education. In N. W. Gleason (Ed.), Higher education in the era of the fourth industrial revolution (pp. 25). Palgrave Macmillan.

Li, T. L., \& Tien, T. L. (2011). Investigating soft skills for success in the workforce: Perceptions of elementary school teachers. International Review of Social Sciences and Humanities, 1(2), 140149. https://pdfs.semanticscholar.org/c2de/9c6457f00e66a20d9cb06863ff37993bc0a8.pdf?_ $\mathrm{ga}=2.192251938 .940181715 .1581490410-877842986.1581490410$

Majid, S., Liming, Z., Tong, S., \& Raihana, S. (2012). Importance of soft skills for education and career success. International Journal for Cross-Disciplinary Subjects in Education, 2(2), 1036-1042. https://www.researchgate.net/publication/307710561

Maphosa, C., \& Mashau, S. T. (2014). Examining the ideal 21st century teacher education curriculum. International Journal of Educational Sciences, 7(2), 319-327. http://doi.org/10.1080/09751122. 2014.11890194

Menon, J., \& Fink, A. (2019). The fourth industrial revolution and its implications for regional economic integration in ASEAN. Journal of Asian Economic Integration, 1(1), 32-47. http://doi. org $/ 10.1177 / 2631684618821566$

Kementerian Riset, Teknologi, dan Pendidikan Tinggi. (2017). Pedoman penyelenggaraan pendidikan profesi guru. [Ministry of Research, Technology and Higher Education. (2017). Guidelines for the implementation of teacher profession education]. https://kelembagaan.ristekdikti.go.id/wp-content/uploads/2017/08/Pedoman-Penyelenggaraan-PPG.pdf

Moustakas, C. (1994). Phenomenological research methods. SAGE.

Muhammad, A., Lebar, O., Mokshein, S. E., \& Baharom, S. (2017). E-portfolio assessment in measuring soft skills in teacher education program: Preliminary findings. International Journal of Academic Research in Business and Social Sciences, 7(6), 991-1003. http://hrmars.com/hrmars_papers/E-Portfolio_Assessment_in_Measuring_Soft_Skills_in_Teacher_Education_Program_Preliminary Findings.pdf

Pachauri, D., \& Yadav, A. (2014). Importance of soft skills in teacher education programme. International Journal of Educational Research and Technology, 5(1), 22-25. http://soeagra.com/ijert/ ijertmarch2014/5.pdf

Parlamis, J., \& Monnot, M. J. (2018). Getting to the CORE: Putting an end to the term "soft skills". Journal of Management Inquiry, 28(2), 1-3. http://doi.org/10.1177/1056492618818023

Pretorius, S. G. (2004). Issues and trends in teacher education in international perspective. Africa Education Review, 1(1), 46-64. http://doi.org/10.1080/18146620408566269

Sambell, K., Brown, S., \& Graham, L. (2017). Professionalism in practice: Key directions in higher education learning, teaching and assessment. Palgrave Macmillan.

Schäfer, M. (2018). The fourth industrial revolution: How the EU can lead it. European View, 17(1), 5-12. http://doi.org/10.1177/1781685818762890

Schwab, K. (2016). The fourth industrial revolution. https://luminariaz.files.wordpress.com/2017/11/ the-fourth-industrial-revolution-2016-21.pdf

Sonmez, J. (2015). Soft skills: The software developer's life manual. Manning.

Subramaniam, I. (2013). Teachers perception on their readiness in integrating soft skills in the teaching and learning. IOSR Journal of Research \& Method in Education, 2(5), 19-29. https://pdfs.semanticscholar.org/9f22/080bf3e8cf61dd58a56a8e3292b2d54e0e13.pdf

Succi, C., \& Canovi, M. (2019). Soft skills to enhance graduate employability: Comparing students and employers' perceptions. Studies in Higher Education, 1-14. http://doi:10.1080/03075079.2019.1 585420

Tan, C. Y., \& Tang, K. N. (2015). A study on soft skill development among final year diploma in business studies students. Malaysian Online Journal of Educational Management, 3(2), 32-50. https://mojem.um.edu.my/article/view/6088

Tang, K. N., \& Tan, C. C. (2015). The importance of ethics, moral and professional skills of novice teachers. Procedia-Social and Behavioral Sciences, 205, 8-12. http://doi.org/10.1016/j.sbspro.2015.09.004 
Jefri MAILOOL, Heri RETNAWATI, Samsul ARIFIN, Ameliasari Tauresia KESUMA, Himawan PUTRANTA. Lecturers' experiences in teaching soft skills in teacher profession education program (TPEP) in Indonesia

PROBLEMS

OF EDUCATION

IN THE $21^{\text {st }}$ CENTURY Vol. 78, No. 2, 2020

230

Tang, K. N., Tan, C. C., \& Vetriveilmany, U. D. (2015). Critical issues of soft skills development in teaching professional training: Educators' perspectives. Procedia-Social and Behavioral Sciences, 205, 128-133. http:/doi.org/10.1016/j.sbspro.2015.09.039

Tang, K. N., Yunus, H. M., \& Hashim, N. H. (2015). Soft skills integration in teaching professional training: Novice teachers' perspectives. Procedia-Social and Behavioral Sciences, 186, 835-840. http://doi.org/10.1016/j.sbspro.2015.04.204

Trilling, B., \& Fadel, C. (2009). 21st century skills: Learning for life in our times. Jossey-Bass.

Tsankov, N. (2017). Development of transversal competences in school education (A didactic interpretation). International Journal of Cognitive Research in Science, Engineering and Education, 5(2), 129-144. http://doi.org/10.5937/IJCRSEE1702129T

WEF. (2016). The future of jobs: Employment, skills and workforce strategy for the fourth industrial revolution. World Economic Forum.

WHO. (1999). Partners in Life Skills Education. Department of Mental Health, World Health Organization.

Wilmarth, S. (2010). Five socio-technology trends: That change everything in learning and teaching. In H. H. Jacobs, Curriculum 21: Essential education for a changing world (pp. 80-96). ASCD.

Zhang, A. (2012). Peer assessment of soft skills and hard skills. Journal of Information Technology Education: Research, 11, 155-168. https://doi.org/10.28945/1634

\section{Appendix}

\section{Appendix A. Approval form for participation}

Dear Participant,

\section{Approval Form for Participation}

We provide this information for you to ascertain whether you wish to participate in our research or not. You need to know that you are free to decide not to participate or even stop at any time in our research without any consequences.

The purpose of our research is to understand the soft skills teaching for pre-service teachers in TPEP implementation. Our research is a phenomenological research that will explore lecturers' experience in teaching soft skills to pre-service teachers during TPEP implementation.

Data collection in our research will be carried out through an in-depth interview process. In the interview process, we use an open-ended interview protocol and a voice recording tool. We also inform you that the individuals who will be involved in collecting this data are the lecturers in the TPEP.

Do not hesitate to ask us about this research, both before participating and while you participated. We are happy and open to share information related to the findings in this research. You also need to know that we fully guarantee the confidentiality of your identity in relation to our research and that only researchers know your identity as a participant.

Please sign your agreement with a full understanding of the nature and purpose of these procedures. A copy of this approval form will be given to you for saved.

Date,

Participant Signature 


\section{Appendix B. Open-ended Interview Protocol}

\section{Open-ended Interview Protocol}

Interview Protocol: Soft Skills Teaching to Pre-service Teachers in the Teacher Profession Education Program (TPEP)

Date

Time

Location

Interviewee

\section{Introduction}

Hello!, my name is Jefri Mailool and I'm a student in Yogyakarta State University. I am conducting research on teaching soft skills for pre-service teachers in the teacher professional education program (TPEP). I am interested in exploring information about the experience of TPEP lecturers in teaching soft skills to pre-service teachers. I plan to ask 10 to 15 TPEP lecturers to share their thoughts and experiences with me.

You were selected to participate in this interview because you are a lecturer teaching in the TPEP. If you are willing to share your thoughts and experiences with me, then I will ask your opinions and experiences related to teaching soft skills for pre-service teachers. There are no right or wrong answers. If you wish, I will record what you say, but I will not write your name. The interview will take 45 to 90 minutes. There is no compulsion in this interview, and you are free to stop whenever you want. Do you have questions for me about my research?

\section{Questions:}

To begin, can you tell me a brief story about yourself?

1. When did you start working as a lecturer?

2. Where did you teach for the first time as a lecturer?

3. Do you like teaching your students? Why?

\section{Now, I will ask about soft skills teaching.}

1. What do you think about the pre-service teacher soft skills?

2. In your opinion, is it important to teach soft skills to pre-service teachers? What is the reason?

3. What kinds soft skills have you trained to pre-service teachers during the TPEP implementation?

4. What is your strategy for teaching soft skills to pre-service teachers during TPEP?

5. How do you evaluate the acquisition of pre-service teachers' soft skills during TPEP implementation?

6. Are there courses specifically designed to train pre-service teachers' soft skills in TPEP implementation? If so, what are they?

7. Are there questions that I didn't ask about soft skills teaching to pre-service teachers and you need explain to me?

Thank you for your willingness to be involved in this interview. I guarantee the confidentiality of all your identity and any answers you give. I will inform you if there is a possibility of further interviews. 
Jefri MAILOOL, Heri RETNAWATI, Samsul ARIFIN, Ameliasari Tauresia KESUMA, Himawan PUTRANTA. Lecturers' experiences in teaching soft skills in teacher profession education program (TPEP) in Indonesia

PROBLEMS

OF EDUCATION

IN THE $21^{\text {st }}$ CENTURY

Vol. 78 , No. 2, 2020

232

Appendix C. Core themes and significant statements about soft skills teaching for pre-service teachers

\begin{tabular}{|c|c|}
\hline Central Themes & Important statements with message examples \\
\hline $\begin{array}{l}\text { Integrated/Embedded } \\
\text { Teaching Model }\end{array}$ & $\begin{array}{l}\text { Special courses that teach soft skills are not listed in the curriculum, but } \\
\text { there is an assessment for the process. } \\
\text { Training that is directly specific to certain soft skills, does not exist } \\
\text { in TPEP... Workshop activities in TPEP, the learning is directly on } \\
\text { deepening the materials such as learning device making. } \\
\text { In the curriculum, TPEP does not appear that there is one course that } \\
\text { specifically teaches soft skills. }\end{array}$ \\
\hline \multirow{5}{*}{ Teaching Methods } & $\begin{array}{l}\text { Lectures: } \\
\text { In the lectures ... I tell them about what their position is like and what } \\
\text { attitudes they should be doing. } \\
\text { While in the class, what behavior should teachers do, how about his or } \\
\text { her manner... including how he or she dresses, how to deal with the } \\
\text { students, and the likes that I will give in my lectures. }\end{array}$ \\
\hline & $\begin{array}{l}\text { Mentoring: } \\
\text { I do observations, and when there are participants whose behavior does } \\
\text { not reflect what is supposed to be a teacher, I will reprimand them and } \\
\text { explain that the position of the teacher should be like this and that they } \\
\text { can put themselves as a professional teacher candidate figure } \\
\text { The program is... workshop.., so we are doing mentoring... Each } \\
\text { instructor has his or her own strategy. } \\
\text { So... there is an element of serving ... our patience, the patience of } \\
\text { colleagues in this task, it is very high ... So, they can keep following. }\end{array}$ \\
\hline & $\begin{array}{l}\text { Presentation: } \\
\text { - The classroom action research that they produce must be presented, and } \\
\text { from there we assess their performance, about how they convey ideas } \\
\text { orally. } \\
\text { When ... doing presentation ... yes ... so ... during the workshops, they are } \\
\text { supposed to construct the KIKD analysis ... well ... after that... there is a } \\
\text { presentation. }\end{array}$ \\
\hline & $\begin{array}{l}\text { Assignment: } \\
\text { I give them a task, in addition to assess their ability, also to train them to } \\
\text { get used to being independent and accountable to their works. } \\
\text { I give them group assignments to train them in forms of cooperation and } \\
\text { how they will contribute to their group. }\end{array}$ \\
\hline & $\begin{array}{l}\text { Practice: } \\
\text { In the workshops ... They should make learning devices. } \\
\text { So... for example, during the workshop, they should make a KIKD } \\
\text { analysis. } \\
\text { TPEP targets are completing the learning devices, making a proposal for } \\
\text { classroom action research, peer teaching, academic and non-academic, } \\
\text { and then exam. } \\
\text { PPL at school... it is for three weeks, then... take about two or three days } \\
\text { off, after that UKIN. }\end{array}$ \\
\hline
\end{tabular}


PROBLEMS

OF EDUCATION

IN THE $21^{\text {st }}$ CENTURY

Vol. 78 , No. 2, 2020
Soft Skills Required

Ethics:

- In the end, it is all about exercising patience. Patience is important to be able to deal with students who are usually late to come to school.

- A good teacher is ... must be patient in guiding their students.

- Teaching students requires patience.

Critical Thinking:

- To develop learning devices, students must think critically because there is a process within which they must analyze carefully.

- Critical thinking is required to design learning devices ... without thinking critically they certainly cannot do it

- In the workshop, the students should produce ...eh... learning devices. So, to make learning devices... it's impossible if without critical thinking.

\section{Communication Skill:}

- The classroom action research that they produce must be presented, and from there we assess their performance, about how they convey ideas orally.

- This peer teaching activity trains them to teach well in front of the class.

- Communication skills in terms of ... group discussions and presentations, ... those are that always being observed.

\section{Self-Reliance:}

- I give them a task, in addition to assess their ability, also to train them to get used to being independent and accountable to their works.

- So... entrepreneurship, if I must interpret it... there must be selfreliance... it means ... it's about how they should be independent as a professional teacher candidate.

- So... DARING is a kind of online learning ... The material is given online, students research independently... they should be able to learn individually.

Responsibility:

- I give them a task, in addition to assess their ability, also to train them to get used to being independent and accountable to their works.

- Submitting the tasks... It must be on time.

Teamwork Skill:

- I give them group assignments to train them in forms of cooperation and how they will contribute to their group.

- The cooperative is full of collectiveness ... So, in one group, it should be observed how they interact to accomplish their tasks.

\section{Tolerance:}

- We also teach the Islamic moderation material as a recommendation from the Ministry of Religious Affairs because we now are facing the phenomenon of radicalism.

- In a dormitory, they are trained to accept diversity, to respect each other.

- When Christian students are praying, Moslem students will contribute to maintaining the atmosphere of the dorm to remain conducive, and vice versa.

\section{Social Skills:}

- In the field experience practice of TPEP ...there are academic and nonacademic... The non-academic one is about how he blends there and being a part of ... eh... the school institution.

- PPL trains them on how to teach students and interact with everyone in the school environment. 
Jefri MAILOOL, Heri RETNAWATI, Samsul ARIFIN, Ameliasari Tauresia KESUMA, Himawan PUTRANTA. Lecturers' experiences in teaching soft skills in teacher profession education program (TPEP) in Indonesia

PROBLEMS

OF EDUCATION

IN THE $21^{\text {st }}$ CENTURY

Vol. 78 , No. 2, 2020

234
Received: December 28, 2019

Cite as: Mailool, J., Retnawati, H., Arifin, S., Kesuma, A. T., \& Putranta, H. (2020). Lecturers' experiences in teaching soft skills in teacher professsion education program (TPEP) in Indonesia. Problems of Education in the $21^{\text {st }}$ Century, 78(2), 215234. https://doi.org/10.33225/pec/20.78.215

\section{Jefri Mailool \\ $\mathrm{PhD}$ (cand), Student, Graduate School of Yogyakarta State University, Jl. Colombo \\ (Corresponding author) \\ Karangmalang Yogyakarta 55281, Indonesia. \\ Lecturer, IAKN Manado, Jl. Bougenville, Tateli I, Minahasa 95661, Indonesia. \\ E-mail: jefri0018pasca.2018@student.uny.ac.id, jefri.mailool@iakn-manado.ac.id \\ ORCID: https://orcid.org/0000-0002-4718-4121}
Heri Retnawati $\quad \mathrm{PhD}$, Professor, Graduate School of Yogyakarta State University, Jl. Colombo Karangmalang Yogyakarta 55281, Indonesia.
E-mail: heri_retnawati@uny.ac.id
ORCID: https://orcid.org/0000-0002-1792-5873

Samsul Arifin $\quad \mathrm{PhD}$ (cand), Student, Graduate School of Yogyakarta State University, Jl. Colombo Karangmalang Yogyakarta 55281, Indonesia.

E-mail: samsularifin.2018@student.uny.ac.id ORCID: 0000-0001-5517-4997

Ameliasari Tauresia Kesuma
PhD (cand), Student, Graduate School of Yogyakarta State University, Jl. Colombo Karangmalang Yogyakarta 55281, Indonesia.

E-mail: ameliasaritauresia.2018@student.uny.ac.id ORCID: https://orcid.org/0000-0003-1057-9282

Himawan Putranta
MEd, Graduate School of Yogyakarta State University, Jl. Colombo Karangmalang Yogyakarta 55281, Indonesia.

E-mail: himawanputranta.2017@student.uny.ac.id

ORCID: 0000-0003-2646-8237 